\title{
蛇紋岩の割れ目分布と変形係数 一山口県宇部市丸尾地域の例一
}

\begin{abstract}
要 旨
山口県宇部市丸尾海岸に露出する未風化の蛇紋岩のボーリングコアにおいて, 割れ目の存在状態掞よび分布形態を記載した。ボーリン グ割れ目柱状図を作成すると，複数の割れ目が集合していくつかのゾーン（割れ目集合体）を形成することが確認された。この蛇紋岩体 における割れ目集合体には，一般に 5 ２0枚程度の割れ目が含まれ，平均割れ目間隔は約 $20 〜 40 \mathrm{~mm}$ であった，一方，同じボーリング孔で 実施した孔内水平載荷試験では，変形係数30〜 500MPaを計測した。この值を，割れ目集合体の分布に対応した局所的な変形係数に換算 し直すと，それはほとんどの割れ目集合体で約30４0MPaに集中しており，割れ目に乏しい部分に比べて1/10程度を示した。割れ目集 合体の変形係数は, 未風化の蛇紋岩で変形が集中する最も弱いゾーンでの平均的な変形係数を示していると考えられる.
\end{abstract}

Key words：割れ目分布 fracture distribution，割れ目集合体 fracture zone，変形係数 deformation modulus，蛇紋 岩 serpentinite

\section{1. はじめに}

蛇紋岩は地すべりや膨張性地山など応用地質的な問題が 多い岩石である ${ }^{1) ~ 3)}$ 。これは蛇紋岩が初生的に構造運動を 受けて形成される際に，塊状，片状〜葉片状など多様な岩 相が発達するうえに, 後生的にも様々な程度に風化・粘土 化することによって，岩盤の状態変化が著しいことが大き な原因になっていると考えられる。蛇紋岩の問題を詳細に 理解するためには，状態変化の初期条件となる未風化岩盤 での特性をまず明らかにする必要がある。

今回, 山口県宇部市丸尾海岸に露出する未風化の蛇紋岩 体において，ボーリング調査と孔内水平載荷試験を行った 載荷試験によって得られる変形係数（弾性係数）は，岩盤 の力学的特性に関して強度と並ぶ材料の 2 大基本特性 ある。これまで変形係数は多くの載荷試験に基づいて主と して岩級区分（あるいは岩盤区分 ${ }^{5)}$ ，岩盤分類5)）との関 係で議論されてきたが ${ }^{5)}$, 最新の岩盤試験データベース を見てもここ 20 年以上, 議論の観点はあまり変わってい ない. 変形係数に影響する要素には多くのものがあるが, なかでも割れ目は未風化岩盤では最も重要な要素であり, 岩盤力学は“割れ目の力学 ${ }^{8}$ ”よばれることがある。割れ 目による変形係数の解釈はこれまで主として割れ目の間隔

*常盤地下工業(株) Tokiwa Underground Engineering Co., Ltd.（会員）

E-mail : h.tsuda@tokiwack.co.jp
によって決まるボーリングコア形状やRQD（Rock Quality Designation）などに着目する程度であって，これらの取 扱い以上に定量的な割れ目分布との関係が議論されること はあまりなかった。この理由の 1 つには割れ目分布の記載 が十分でなかった面がある。

この点で，先に著者はボーリング孔における割れ目分布 の記載に重点をおいた「ボーリング割れ目柱状図」の作製 を提唱した ${ }^{9)}$. 津田 ${ }^{9)}$ は, 割れ目は一様あるいは不規則に 分布するのではなく，何枚か集まって「割れ目集合体」を 形成することを明らかにした。割れ目集合体とは，これま でボーリングコア（以下，コア）ではある深度に集合した 割れ目のゾーンとして記載されてきたものである。割れ目 集合体は岩盤中で変形が集中する弱いゾーンとなるため, 割れ目がそしいゾーンと比べて，割れ目集合体の変形係数 が低いことは明らかである。したがって，漠然と高い低い という一般論に終わるのではなく，孔内水平載荷試験によ る変形係数と割れ目集合体の変形係数との対応関係を明ら かにする必要がある。

そこで, 丸尾海岸での未風化の蛇紋岩コアを例として, 割れ目スケッチからボーリング割れ目柱状図を作成し，割 れ目集合体の記載に基づいて，割れ目分布と変形係数との 関係を示す。また，割れ目集合体の変形係数に言及する。 なお割れ目（fracture）とは，岩盤中に肉眼で明瞭な密着 状〜開口状の隙き間をなし，脆性破壊によって割れている 不連続面を総称するものである ${ }^{9)}$ 10)。亀裂 (crack) とは 小さい割れ目を指すことが多く ${ }^{10)}$ ，本稿ではこの用語は用 
いない。また，ハンマー打診などに伴う人為的な割れ目は 観察対象から除外する。

\section{2. 丸尾地域の地質概要と蛇紋岩の岩相}

\section{1 地質概要}

山口県宇部市丸尾地域には蛇紋岩類 ${ }^{11}, 12$ が広く分布する (図-1)。これらは中生代三畳紀の地層である周防変成岩 中 $\left.{ }^{111}, 12\right)$ に挟在し，蛇紋岩メランジを構成する ${ }^{13)}$ 。また，白 亜紀の広島花崗岩によって接触変成作用を受け，蛇紋岩中 の割れ目には方解石, ドロマイト, マグネサイトなどの炭 酸塩鉱物が生じている ${ }^{122}$.

丸尾海岸の蛇紋岩（以下，丸尾蛇紋岩）では, 海食を受 け風化・粘土化部分がほとんど取り去られた未風化岩盤が 広く露出して扮り（図-1），今回の海岸付近のボーリング 調査においてもこれと同じ蛇紋岩が存在することを確認し た。一般に産出する蛇紋岩はしばしば風化・粘土化してい るが，今回の蛇紋岩コアには割れ目は多いものの，そうし た風化はほとんど認められず，その意味で未風化岩盤と表 現しておく。

丸尾蛇紋岩の岩相は肉眼で片状岩相と塊状岩相に大別さ れる。片状岩相の片理面は全体に波状に起伏し，うねりが 著しい，割れ目には節理・小断層・片理面に沿った割れ目 の 3 種があり，片理面に沿った割れ目が多い，割れ目分布 には粗密があり,割れ目が集中するゾーン（割れ目集合体）
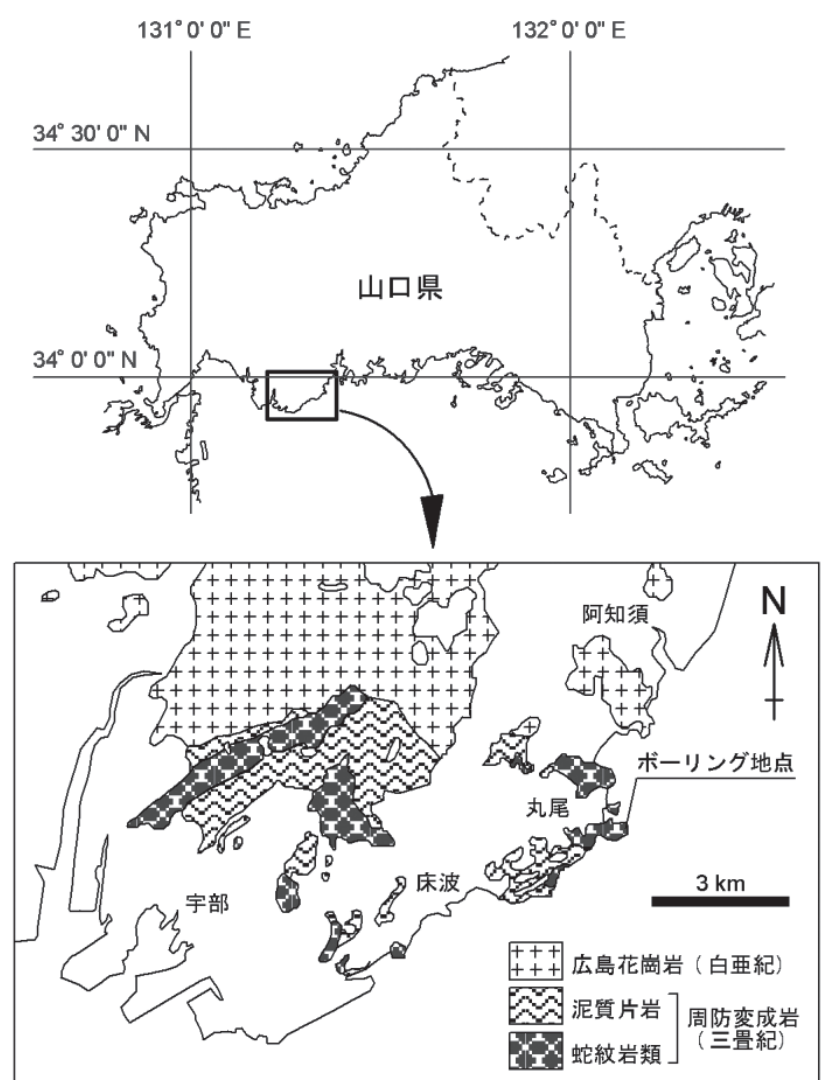

図-1 山口県宇部市丸尾地域の蛇紋岩類

西村ら ${ }^{11)}$ から調査地周辺の関連する地質を抽出した。
の存在が認められる（写真-1）。割れ目集合体は不規則に うねり, 複雑に分岐・交差・尖滅しながら全体としてつな がっているものが観察される。

\section{2 コアにおける蛇紋岩の岩相}

丸尾蛇紋岩のコア写真, 割れ目スケッチ㧍よび岩相/岩 級区分図を，図-2に示す。コアは長さ7.0mであり，孔内 水平載荷試験（後述）を連続的に行い一連の変形係数を得 ている。このコアは, 回転式スピンドル型の油圧ボーリン グでスリーブ内蔵ダブルコアチューブによって採取した鉛 直コアである，掘削ビッドはインプリグネイテッド型のダ イヤモンドビッドで外径 $66 \mathrm{~mm}$ ，コア径 $48 \mathrm{~mm}$ である。なお， 孔内地下水は認められなかった。

図-2の蛇紋岩は, 媣度0.7 4.3m付近まで片状岩相, 深 度4.3 7.0mまでは塊状岩相がそれぞれ卓越し, 岩相ごと に割れ目分布が異なる，以下，岩相ごとの特徵を記す。

\subsection{1 片状岩相 (Sg)}

片状岩相は主として暗緑〜淡緑色を帯びる不均質な部分 が混在して片状構造をなす岩相である（図-2のSg），この うち暗緑層では滑感・脂肪光沢を呈することが多く, 方解 石脈を部分的に伴う。岩級区分では $\mathrm{C}_{\mathrm{M}}$ 級に相当するもの
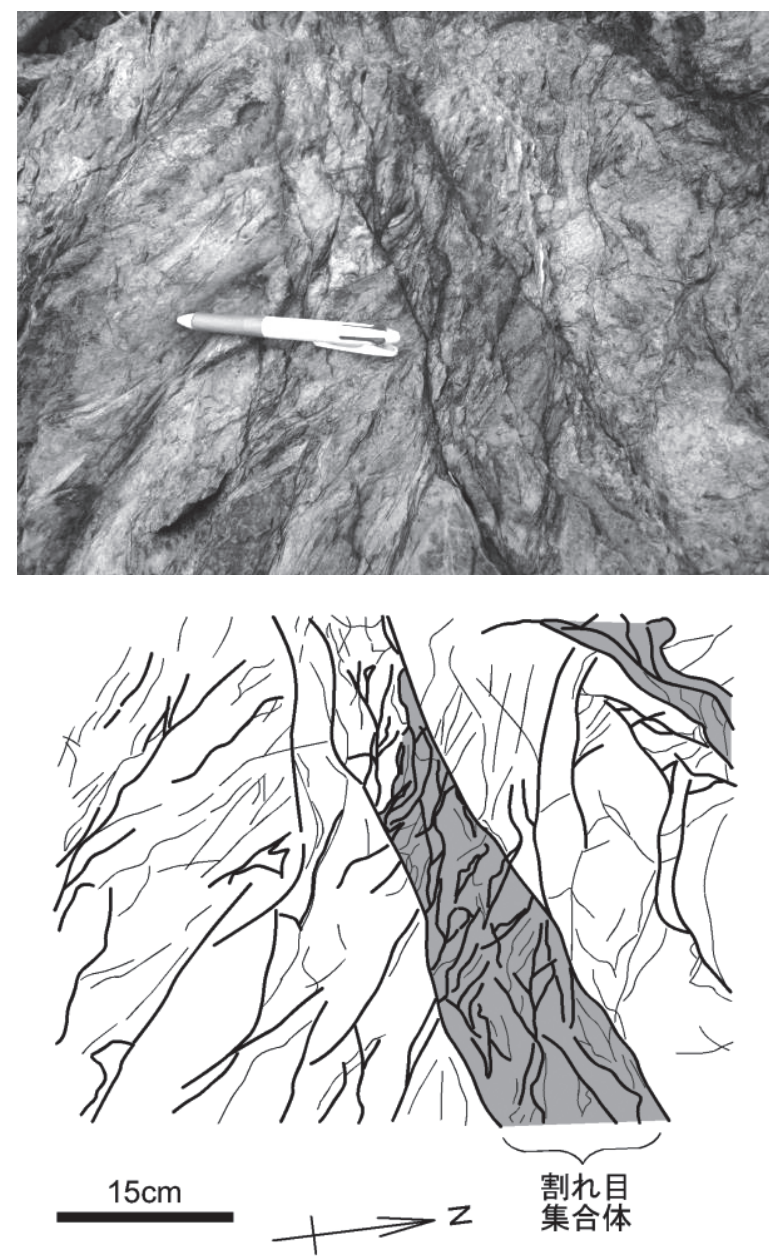

写真-1丸尾海岸での蛇紋岩露頭の例

割れ目分布には粗密があり，割れ目集合体が存在する。 


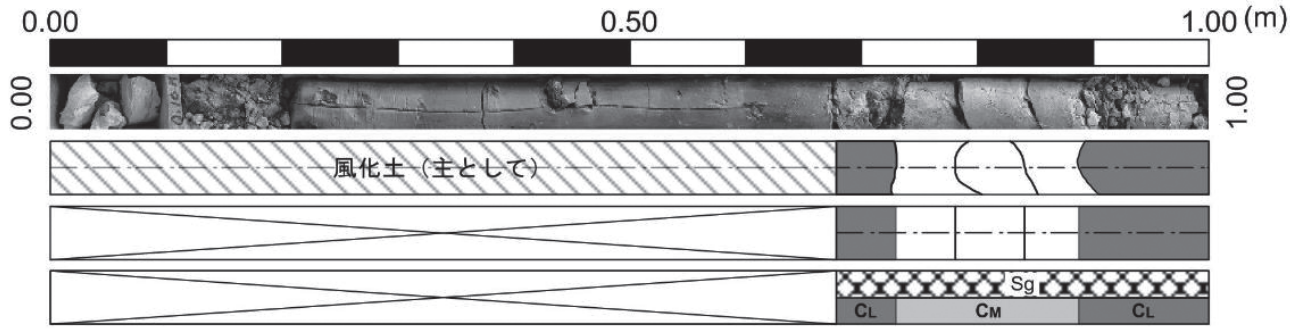

: Pa

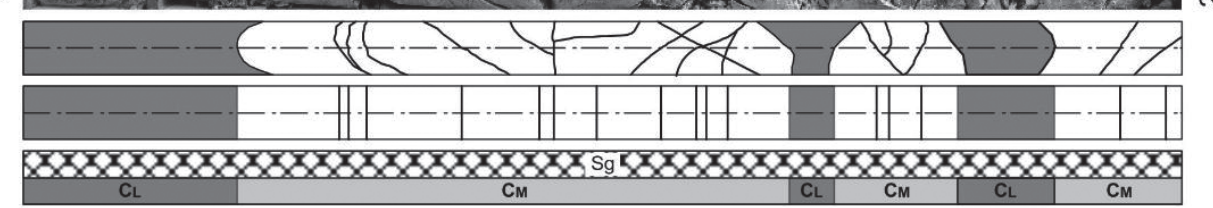

$\stackrel{\leftrightarrow}{\mathrm{i}}$

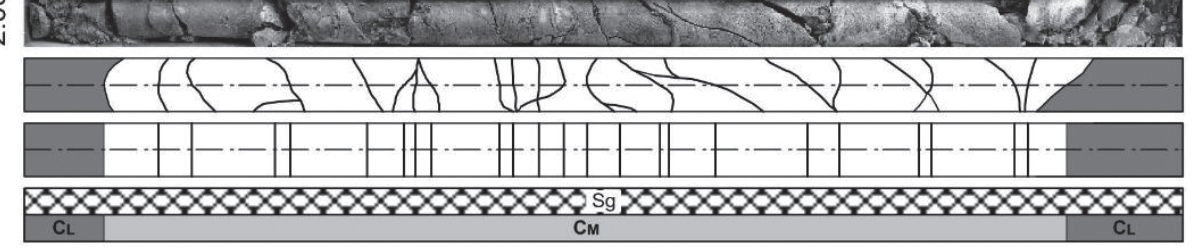

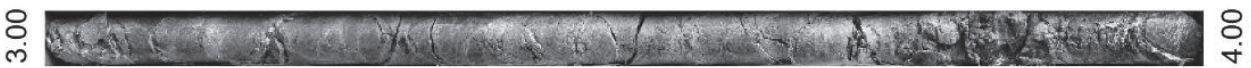

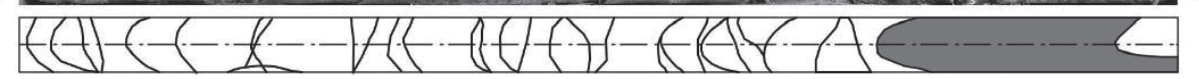

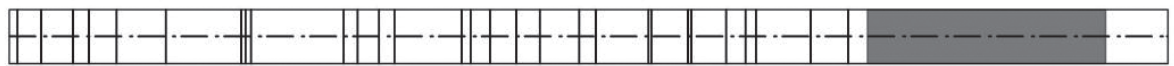
$\frac{\operatorname{coc}_{\mathrm{M}}}{\max }$

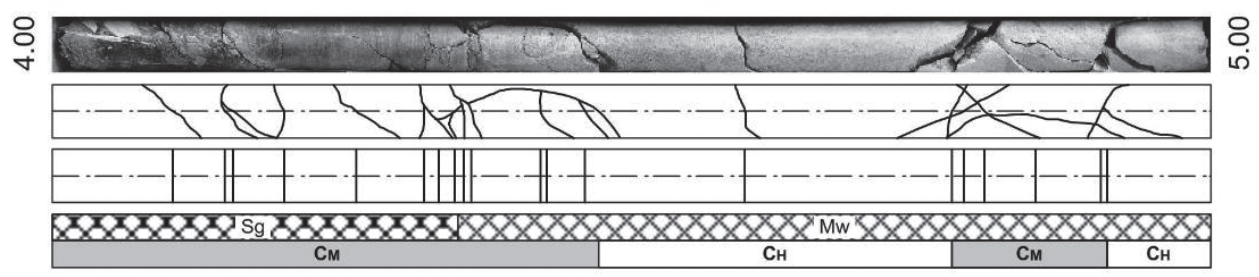

is atrory

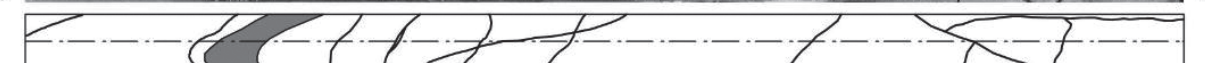

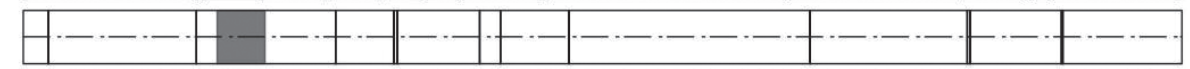

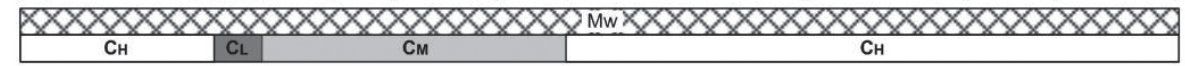

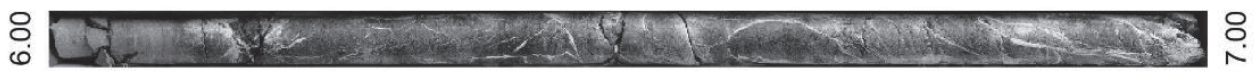

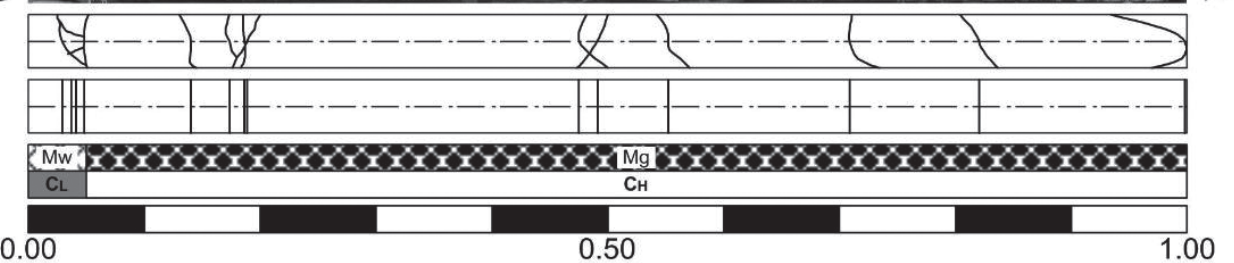
岩相 $\mathrm{Sgd}$ 片状岩（暗緑〜淡緑色）
Mw 塊状岩(灰白色)
IMg] (暗緑色)
岩級 $\mathrm{CH}$ コア長10-30cm程度(新鮮)
CM コア長5-15cm程度以下 (比較的新鮮)
$\mathrm{CL}$ 角磷状 (数cm以下の角础，一部軟筫化）

図-2 丸尾蛇紋岩のコア写真, 割れ目スケッチおよび岩相/岩級区分図 
が多い.

割れ目は全体に数十 $\mathrm{mm}$ 以下の割れ目間隔で比較 的密に存在するものが多いが，コアは円柱状を保 つ. 固着している片理面は指圧〜ハンマー軽打程 度では分離しない，片理面が転化した割れ目面は 湾曲〜凹凸状をなすことがある。また，割れ目面 上には不定形の滑石や瀻維状の蛇紋石が認められ ることがある。深度 $4.0 \mathrm{~m} の$ 方解石脈では脈沿い に割れ目が存在している.

また，片状岩相には割れ目の密集によって角硫 状をなす部分 $\left(\mathrm{C}_{\mathrm{L}}\right.$ 級 $)$ が $200 \mathrm{~mm}$ 以下の厚さで所々 挟在する, 角砂状部は砂径数十 $\mathrm{mm}$ 以下をなし, 各 割れ目は区別できないほどに密集している，深度 0.9 1.2m付近, 2.0m付近, 2.9 3.0m付近, 3.8 $4.0 \mathrm{~m}$ 付近の角䃏状部では岩質が軟化している部 分が局在する.

\subsection{2 塊状岩相 $(\mathrm{Mw}, \mathrm{Mg})$}

塊状岩相には, 灰白色で炭酸塩鉱物に富み, ざ らつき感を呈する岩相（図-2の Mw, 深度4.3〜 6.0m） と, 暗緑色で滑感・脂肪光沢があり, 方 解石脈を多く伴う岩相（図-2の Mg，深度6.0 $7.0 \mathrm{~m}$ )とがある。これらの割れ目は全体に少な

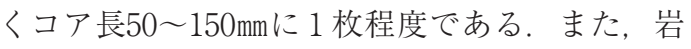
級区分ではC $\mathrm{C}_{\mathrm{H}}$ 級に相当するものが多い.

$\mathrm{Mw}$ 相の深度 $4.4 \mathrm{~m}, 4.8 \mathrm{~m}, 5.4 \mathrm{~m}, 5.9 \mathrm{~m}$ 付近では, コア軸に平行する高角度の割れ目が湾曲して存在 する（図-2）。深度 $5.2 \mathrm{~m} に は$ 角磉状部を $50 \mathrm{~mm}$ 程度 の厚さで挟在する。また，深度6.2 7.0mには方 解石脈が多いが固着しており, 前章で述べた割れ 目は生じていない.

\section{3. 蛇紋岩の割れ目分布の記載}

\section{1 ボーリング割れ目柱状図と割れ目間隔図 の作成}

ボーリング割れ目柱状図（以下, 割れ目柱状図) の作成法については，津田帛にしたがう。ただし， 今回は割れ目の方向や開口幅など割れ目そのもの の観察は目的ではないため, ボアホールテレビカ メラ観察を用いず，コアの割れ目スケッチ（図 -2）に基づいて，図-3のように割れ目柱状図と割 れ目間隔図を作成した。

\subsection{1割れ目柱状図の作成}

各々の割れ目の位置 (深度) と相互の割れ目間 隔を特定するため, 割れ目スケッチ（図-2）上に おいて、コア中心線を設け，これとコアに現れた 割れ目の線が交わる点の深度を割れ目の深度とし， 割れ目を直線（角砂状部を四角形）で図示した。

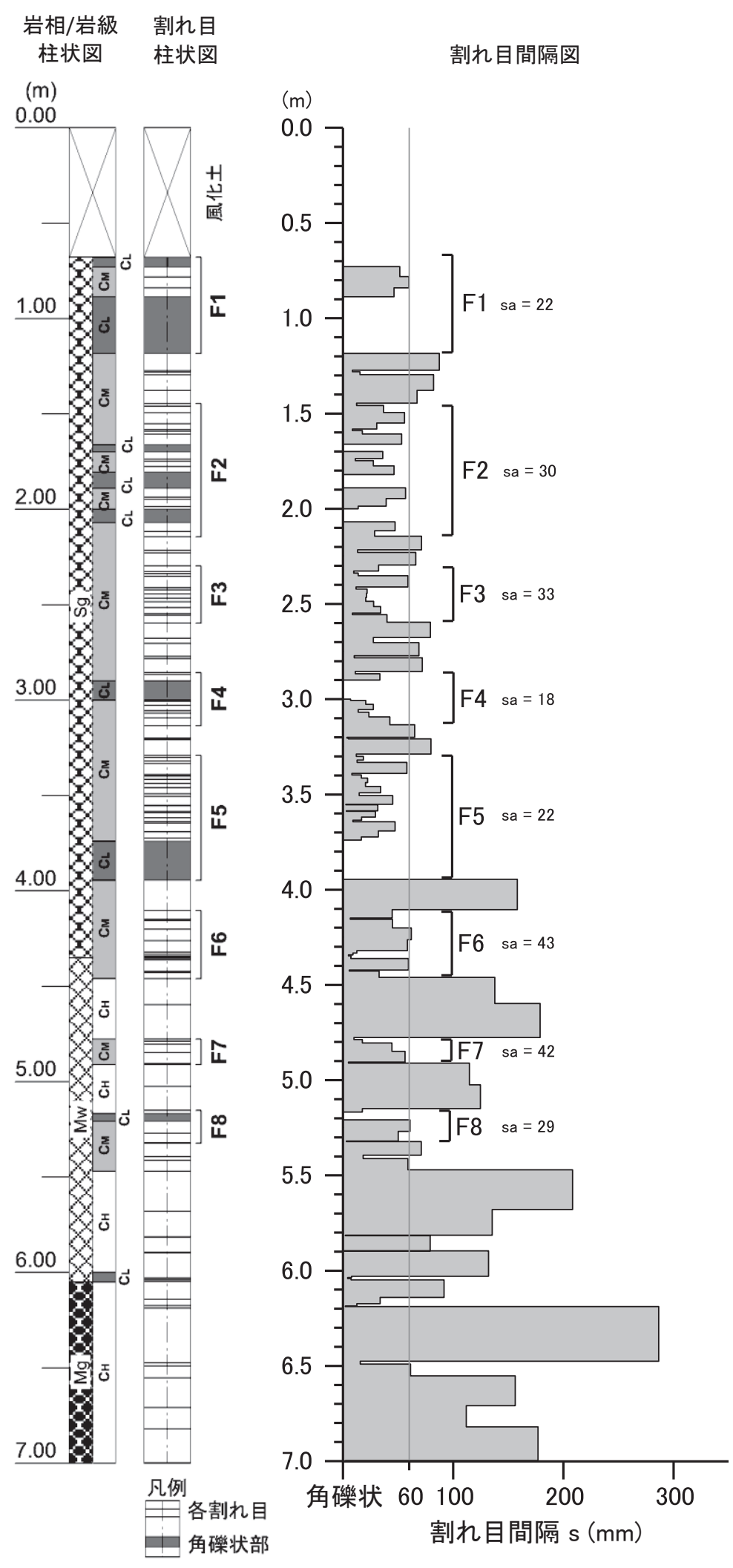

図-3 岩相/岩級柱状図, 割れ目柱状図および割れ目間隔図

$\mathrm{F} 1 \sim \mathrm{F} 8$ ：割れ目集合体，5枚程度以上の各割れ目が $60 \mathrm{~mm}$ 程度以下の割れ 目間隔で集合する割れ目ゾーン

今回の割れ目集合体の抽出では, 割れ目間隔 $\mathrm{s} か ゙ 60 \mathrm{~mm}$ の線を参考線とした. $\mathrm{sa}$ : 平均割れ目間隔 $(\mathrm{mm})$

岩相/岩級柱状図の凡例は図-2と同じ. 
コア中心線に交わらないコアに平行する割れ目は, スケッ チした割れ目の線の中点を割れ目の深度とした（図-2）.

また，これらの深度区分は接近した割れ目どうしを区分で きるようにmm単位とした。図-3の割れ目柱状図は図-2の $1 \mathrm{~m}$ ごとの割れ目スケッチを深度方向に継ぎ合わせて作成 した。なお,コアに平行する長い割れ目が多いと, 割れ目 の深度の特定が難しくなり割れ目柱状図を作成する意味は そしくなると考えられる。

\subsection{2 割れ目間隔図の作成と平均割れ目間隔の算出法}

割れ目間隔図（図-3）では，割れ目柱状図での各割れ目 の深度を縦軸（1 目盛 $0.1 \mathrm{~m} ） に$ に隣り合う割れ目どうし の間隔を横軸（1目盛 $100 \mathrm{~mm}$ ) に表した。

割れ目間隔は一様ではないため, 全体のグラフ形状は階 段形状となる。隣り合う割れ目間隔が狭ければ階段の幅は 狭く高さは低くなり, 間隔が広ければ階段の幅は広く高さ は高くなる。グラフの階段面積は，着目した深度区間での それぞれの割れ目間隔を 2 乗して足し合わせた值となり, グラフ上で単にこうよぶだけの 1 つの指標值である。角礫 状部では割れ目が集中していて間隔が判読できないため, 階段の高さを与えない.

また，角礫状部が存在すると，割れ目間隔の単純算術平 均が算出できないため, 平均割れ目間隔 ( $\mathrm{sa}$, 単位 : mm) は割れ目間隔図での階段の高さ $0 \mathrm{~mm}$ の角礫状部を含めた階 段面積の総和を区間長で除した数值として算出する。前述 の割れ目間隔図の作成過程上, 平均割れ目間隔（sa）は割 れ目間隔の 2 乗（グラフの階段面積）の総和に比例する量 となる。

図-4は割れ目間隔図を用いて saを算出する方法を最も簡 単な1ケースとして示したものであり，単一の割れ目が深 度 $100 \mathrm{~mm}\left(\mathrm{X}_{1}\right)$ と $200 \mathrm{~mm}\left(\mathrm{X}_{2}\right)$ に, 角碩状部が深度500〜 $600 \mathrm{~mm}\left(\mathrm{X}_{3} \sim \mathrm{X}_{4}\right)$ にあったとする.

ここで, 深度100〜600mm $\left(\mathrm{X}_{1} \sim \mathrm{X}_{4}\right)$ ではsa $=\left\{\left(\mathrm{X}_{2}-\mathrm{X}_{1}\right)^{2}\right.$ $\left.+\left(\mathrm{X}_{3}-\mathrm{X}_{2}\right)^{2}+\left(\left(\mathrm{X}_{4}-\mathrm{X}_{3}\right) \times 0\right)\right\} /\left(\mathrm{X}_{4}-\mathrm{X}_{1}\right)=\left\{\left(100^{2}+300^{2}+\right.\right.$ $(100 \times 0)\} / 500=200 \mathrm{~mm}$ となる.

角礫状部を含まない深度 $100 〜 500 \mathrm{~mm}\left(\mathrm{X}_{1} \sim \mathrm{X}_{3}\right)$ では $\mathrm{sa}=$ $\left\{\left(\mathrm{X}_{2}-\mathrm{X}_{1}\right)^{2}+\left(\mathrm{X}_{3}-\mathrm{X}_{2}\right)^{2}\right\} /\left(\mathrm{X}_{3}-\mathrm{X}_{1}\right)=\left(100^{2}+300^{2}\right) / 400=$ $250 \mathrm{~mm}$ となる。この值は割れ目間隔図の各階段面積を重み づけとする加重調和平均と等しく（図-4）, 各割れ目間隔 の単純算術平均 $\left\{\left(\mathrm{X}_{2}-\mathrm{X}_{1}\right)+\left(\mathrm{X}_{3}-\mathrm{X}_{2}\right)\right\} / 2=(100+300) / 2$ $=200 \mathrm{~mm}$ とは異なる.

なお付表-1には, 今回の検討で用いたデータの一覧を示 す. 同表中の深度欄には後述する孔内水平載荷試験の区間 境界を併記している。

\section{2 割れ目集合体と平均割れ目間隔}

図-3の割れ目柱状図での割れ目が密集するゾーンが割れ 目集合体であり, これは割れ目間隔図での階段形状の落ち 込んだゾーンと対応している。

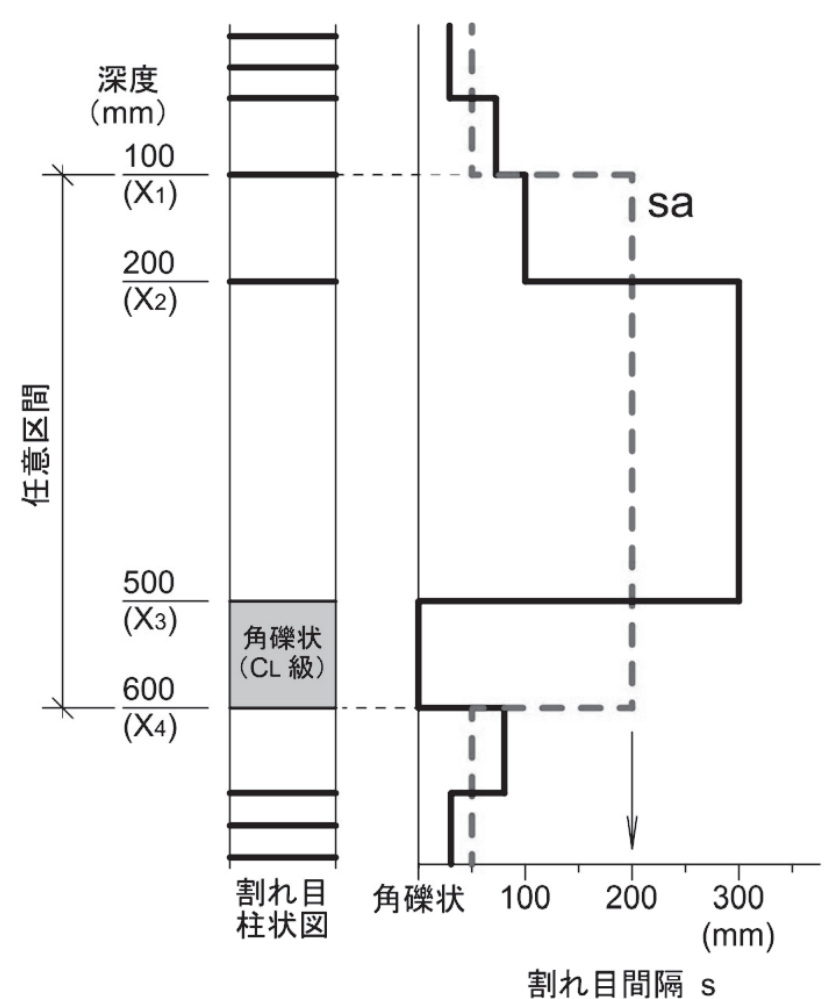

図-4 割れ目間隔図での平均割れ目間隔の算出法

$\mathrm{sa}$ : 平均割れ目間隔 $(\mathrm{mm})$

なお, 深度100〜 $500 \mathrm{~mm}\left(\mathrm{X}_{1} \sim \mathrm{X}_{3}\right)$ において, 平均割れ目 間隔を加重調和平均を用いて計算すると, $\mathrm{sa}=1 /\left[\left\{\left(1 /\left(\mathrm{X}_{2}\right.\right.\right.\right.$ $\left.\left.-\mathrm{X}_{1}\right)\right) \times\left(\left(\mathrm{X}_{2}-\mathrm{X}_{1}\right)^{2} /\left(\left(\mathrm{X}_{2}-\mathrm{X}_{1}\right)^{2}+\left(\mathrm{X}_{3}-\mathrm{X}_{2}\right)^{2}\right)\right\}+\left\{\left(1 /\left(\mathrm{X}_{3}\right.\right.\right.$ $\left.\left.\left.-\mathrm{X}_{2}\right)\right) \times\left(\left(\mathrm{X}_{3}-\mathrm{X}_{2}\right)^{2} /\left(\left(\mathrm{X}_{2}-\mathrm{X}_{1}\right)^{2}+\left(\mathrm{X}_{3}-\mathrm{X}_{2}\right)^{2}\right)\right\}\right]=1 /$ $[\{(1 / 100) \times(1 / 10)\}+\{(1 / 300) \times(9 / 10)\}]=250 \mathrm{~mm}$ となる. ここで, $\left(\mathrm{X}_{2}-\mathrm{X}_{1}\right)^{2} /\left(\left(\mathrm{X}_{2}-\mathrm{X}_{1}\right)^{2}+\left(\mathrm{X}_{3}-\mathrm{X}_{2}\right)^{2}\right)=(1 / 10)$ とは 深度100 500mm $\left(X_{1} \sim X_{3}\right)$ までの階段面積の総和に占める 深度100〜200mm $\left(X_{1} \sim X_{2}\right)$ 区間の階段面積の重みづけ,また, $\left(\mathrm{X}_{3}-\mathrm{X}_{2}\right)^{2} /\left(\left(\mathrm{X}_{2}-\mathrm{X}_{1}\right)^{2}+\left(\mathrm{X}_{3}-\mathrm{X}_{2}\right)^{2}\right)=(9 / 10)$ とは同じく総 和に占める深度 $200 \sim 500 \mathrm{~mm}\left(\mathrm{X}_{2} \sim \mathrm{X}_{3}\right)$ 区間の階段面積の重 みづけである。

割れ目分布の粗密は，割れ目間隔でとらえると全体的に 数mm以下て接近するものから 100 200 mm以上離れているも のまで存在する。コア全体での割れ目分布を考慮し, 孔口 側から割れ目の密集の程度を大局的に見ていく．この見方 は, 割れ目間隔の絶対值に基づくものではなく, コア全体 を見て割れ目が相対的に多い区間を抽出するものである. まず深度0.678〜 1.185mの割れ目は周辺と比べて密集して おり，割れ目集合体と識別できる。これを「1次オーダー の割れ目集合体 $\left.{ }^{9}\right\rfloor$ とし，F1の記号を与える.

以下, 同様に, 深度1.445〜2.145mにF2, 深度2.296 $2.597 \mathrm{~m}$ にF3, 深度2.855 3.135mにF4, 深度3.289〜 $3.946 \mathrm{~m}$ にF5, 深度4.104〜4.460mにF6, 深度4.777〜4.910mにF7, 深度5.149 5.323mにF8, と計8か所の割れ目集合体が抽出 できる（図-3，付表-1），各集合体の厚みはいずれも0.1〜 $0.7 \mathrm{~m}$ 程度である。深度 $6 \mathrm{~m}$ 付近にも割れ目がいくつかある が, これらはF1〜F8に比べて割れ目枚数が少ないことか 
ら集合体とはしない（図-3）.

以上のことをふまえて割れ目集合体を抽出すると，1つ の集合体には $5 \sim 20$ 枚程度の割れ目が包含され，かつ割れ 目間隔は60mm程度以下（図-3）であった。これはこのコア での集合体の 1 つの抽出基準となる.

また，3.1.2項で示した平均割れ目間隔（sa）を集合体の 分布区間ごとに求めると, saは $18 \sim 43 \mathrm{~mm}$ となる（図-3，付 表-1).

\section{4. 孔内水平載荷試験と蛇紋岩の変形係数}

\section{1 孔内水平載荷試験法と变形係数の計測}

孔内水平載荷試験とは，試験孔の孔壁面に対して垂直方 向に載荷し，そのときの圧力と孔壁面の変位から，地盤の 変形係数 (弾性係数), 降伏応力, 極限応力を求める試験 をいう ${ }^{14)}$ ，本稿では変形係数だけに着目する。変形係数 (Db) とは岩石などのように応力ーひずみ関係が必ずしも 直線的でない物体における弾性係数 ${ }^{15)}$ である。Dが高い ほど変形抵抗は大きく，変形しにくい状態にある．

$\mathrm{Db}$ の計測では，地盤工学会基準「地盤の指標值を求める ためのプレッシャーメータ試験方法（JGS1531-2012） ${ }^{14)} 」 に$ したがい，高圧載荷方式（最大 $20 \mathrm{MPa}$ ）である応用地質 製エラストメータMODEL-4022を用いた。この試験機器 では，測定探子のゴム筒（長さ $520 \mathrm{~mm} ）$ にハンドポンプで 注水して孔壁に対し垂直方向へ等圧分布で載荷する。孔壁

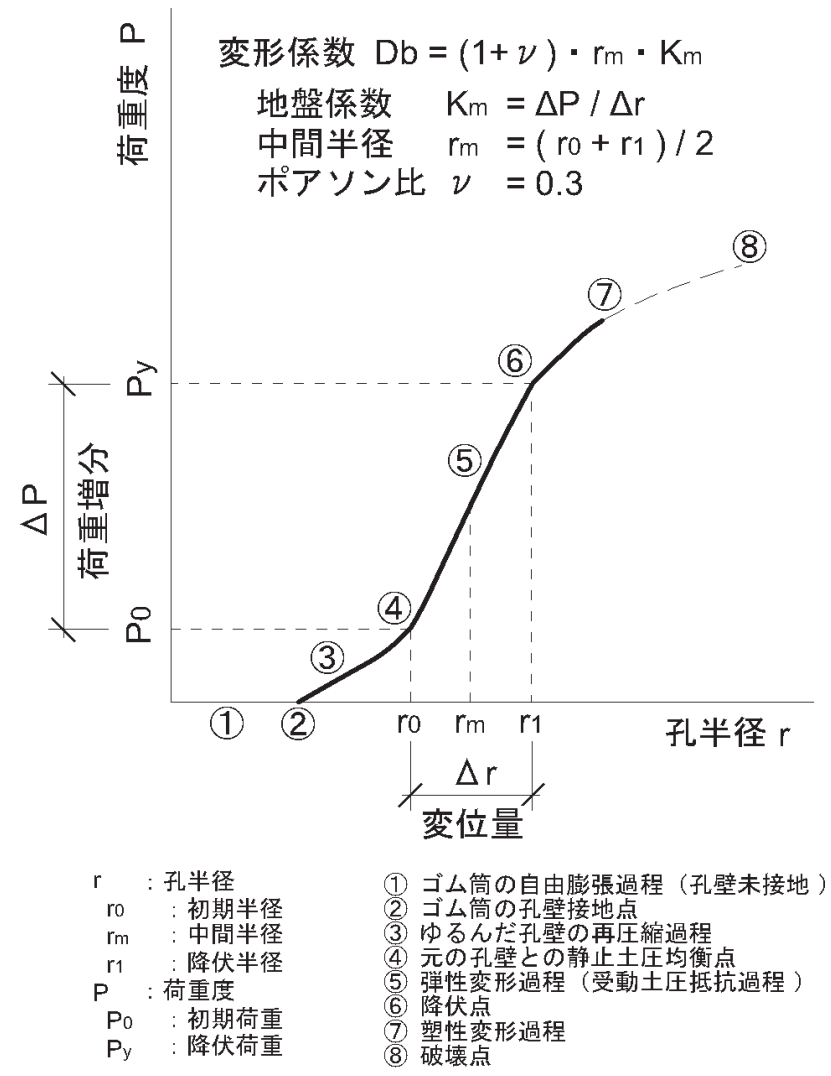

図-5＼cjkstart処女荷重度－孔半径変位曲線（P-r図）の概念図
変位はゴム筒の中央部に内蔵されているキャリパーアーム の開口度によって，ゴム筒の膨張変位として計測される。

また, Dbは処女荷重度 - 孔半径変位曲線 $(\mathrm{P}-\mathrm{r}$ 図, 図-5）における(5)の変形過程の近似直線が急勾配であるほ ど高い数值となる．岩石のポアソン比 $v$ は一般に $0.2 \sim 0.4$ 程度 ${ }^{4)}$ であることを考慮し，0.3とした。また今回のように 試験区間を連続的に区切って載荷する場合では，隣接試験 の影響を可能な範囲で小さくするため，試験中リアルタイ ムでモニター表示されるP-r図で降伏点（図-5の6) を単 調載荷の過程で確認直後, 変位が大きくならないうちに速 やかに除荷し試験を終了した。実際，降伏時の孔壁変位は すべて0.5〜 $1 \mathrm{~mm}$ 程度以下，降伏荷重は 5 10MPa程度で あった。

\section{2 平均割れ目間隔と変形係数との関係}

\subsection{1 載荷試験区間での平均割れ目間隔と変形係数と の関係}

図-3の割れ目柱状図の深度1.25〜 6.25m区間を対象とし

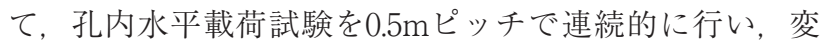
形係数を計10回計測した。載荷試験探子のゴム筒長さは前 述のように $520 \mathrm{~mm}$ であるため, 隣り合う試験区間 $(0.5 \mathrm{~m})$ どうしでのゴム筒の重複や，ゴム筒を取りつけたボーリン グロッドの昇降に伴う試験区間の設置誤差の影響が実際の 試験值には含まれる。

図-3に10回の試験区間（1～～(10)）の変形係数（Db）の 值を加え，図-6とした。これらのDbは30〜 500MPaであっ た。 また図-6には，3.1.2項に基づいて計算した試験区間ご との平均割れ目間隔（sa）の值を併記した（詳細は付表 -1).これらのsaは30〜120mmであった。

図-6のDb-sa関係は図-7となり，正の相関が有意に認め

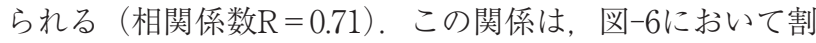
れ目間隔図とDbの梁度分布図のグラフ形状が大まかには 類似していることからもうかがえる。

以上のように丸尾蛇紋岩では，割れ目が多いほど（割れ 目間隔が狭くなるほど), 変形係数が低くなることが確認 される（図-7)。このことは，一般に節理頻度（Joint Frequency ${ }^{16)}$ ) は岩石中に蓄積されるひずみエネルギーと 比例関係をもち，岩石の弾性係数に関係すること ${ }^{16), 17)}$ と整 合的である.

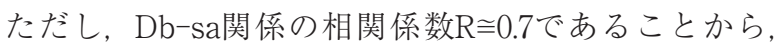
割れ目分布だけでは説明できない余分が残る。この原因に は，割れ目それ自身の特性（開口幅, 含水状態など）や, 載荷試験法上の制約（試験区間の取り方など）があるので はないかと考えられる。

\subsection{2 割れ目集合体の平均割れ目間隔と変形係数との 関係}

蛇紋岩（結晶片岩）は片理に沿って割れやすいこと ${ }^{1)} と$ 同様，一般に岩盤が変形する際には，割れ目がない部分が 

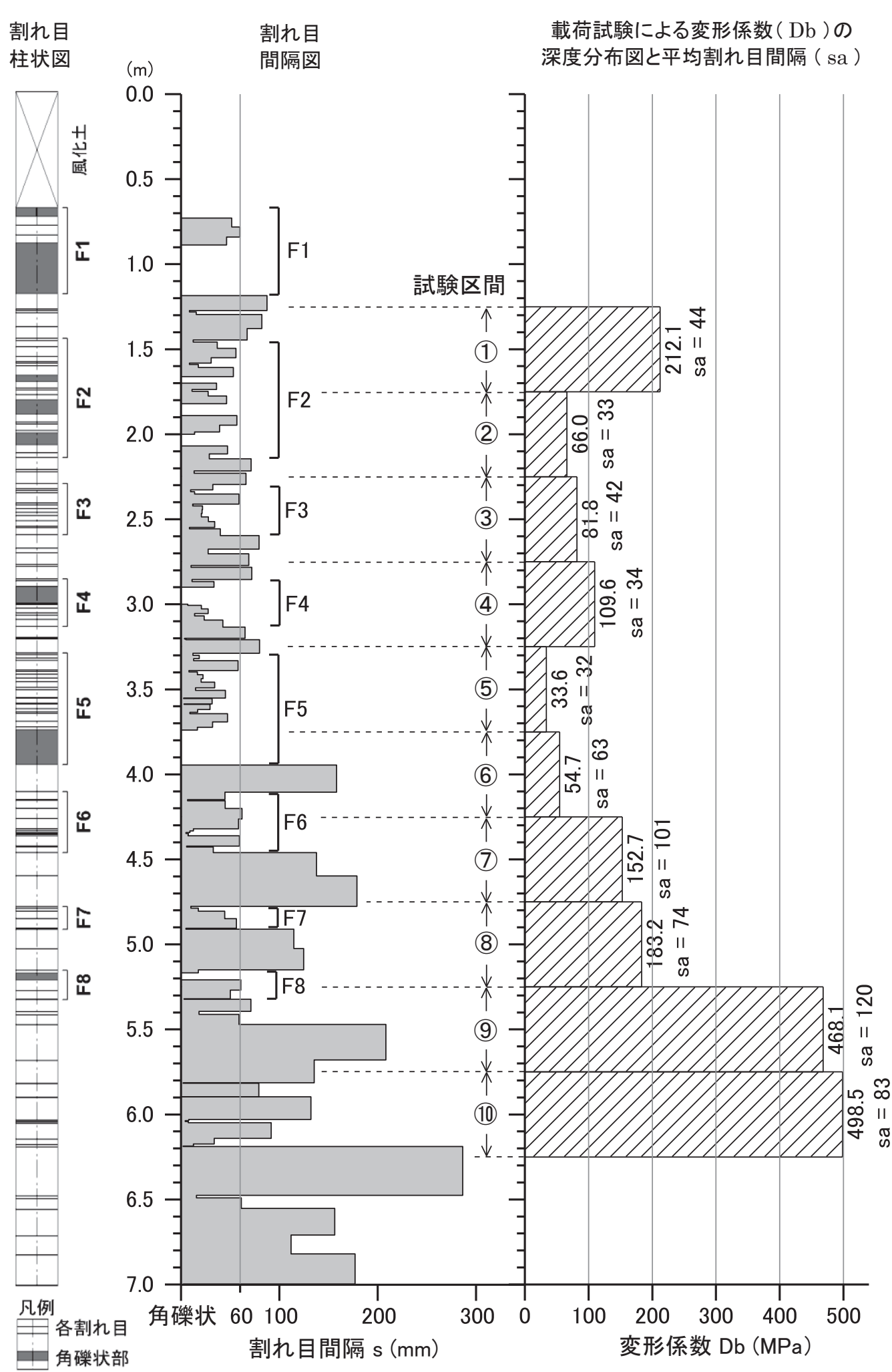

図-6 割れ目柱状図，割れ目間隔図および变形係数の深度分布図

凡例は図-3と同じ.

脆性破壊して新たに割れ目が発生するよりも，すでに破壊 された断層などの弱線部あるいは既存の割れ目から変形が 進行する ${ }^{18)}$ 。この意味においては, 割れ目の多いゾーンで ある割れ目集合体の変形係数が欠かせない.

一方，孔内水平載荷試験によるDbは，試験区間での平
均化された巨視的な変形係数（巨視的弾性係数吕) である この試験は，4.1節で述べたように試験法上の制約から一 定区間を区切って行われ，任意の試験区間長を設けること はできない。試験区間がコアスケッチで特定した割れ目分 布とは必ずしも対応せず，得られた変形係数（Db）は割 
れ目集合体をまたいだり（例えば，F2，図-6）, あるいは試験区間中に割机目集合体を内包したり （例えば，F4，図-6）するためである。

そこで，次に各試験区間で得られた変形係数 （Db）から, 割れ目集合体の変形係数（Dbz）を 推測する方法について述べる。これは, 割れ目間 隔図の階段面積から算出した平均割れ目間隔 (sa) が載荷試験区間での変形係数（Db）との間に有 意の相関性（図-7）があり，また，割れ目集合体 $\mathrm{F} 1 \sim 8$ の厚みは約 $0.1 \sim 0.7 \mathrm{~m}$ であり, 載荷試験区 間のスケール $(0.5 \mathrm{~m})$ と大差はないことに基づい ている.

[割れ目集合体の変形係数の推測法]：例えば, 図-6のF4（深度2.855～3.135m）は載荷試験区間 $2.75 \sim 3.25 \mathrm{~m}$ （変形係数 $\mathrm{Db}=109.6 \mathrm{MPa}$ ）の間に内 包される，以下，F4の変形係数を推測する。

載荷試験2.75～3.25m間に対応する割れ目間隔 図のグラフ上の階段面積（割狆目間隔の 2 乗の総 和）は16,806m ${ }^{2}$ である（付表-1）。この階段面積 が変形係数 $\mathrm{Db}=109.6 \mathrm{MPa}$ と対応する. F4の階段 面積は5,070mm ${ }^{2}$ であり，これに対して変形係数を 割りふると, $\mathrm{Dbz}=109.6 \mathrm{MPa} \times 5,070 \mathrm{~mm}^{2} / 16,806$ $\mathrm{mm}^{2}=33.1 \mathrm{MPa}$ となる (付表- 1 ).

また，割れ目集合体F2のように，集合体が載 荷試験区間をまたいでいる場合も同様にして，ま たいでいる集合体区間どうしでの割りふった変 形係数を最後に足し合わせる (付表-1).

このようにして，割れ目間隔図の階段面積（割 れ目間隔の 2 乗の総和）を指標とすることによっ て, 載荷試験区間で得られた変形係数を割れ目集 合体の変形係数に比例配分して割りふる。

以下同様にして，割れ目間隔図を用いて割れ目 集合体の変形係数（Dbz）を推定した結果を図 -7 のプロットに加えると, Dbz-sa関係は図-8のよ うになる。倠蛇紋岩での各割れ目集合体ごとの 変形係数は，ほとんどが30〜40MPaでほぼ一定 の值に集中し，それらの平均割れ目間隔（sa）は 20〜40mm程度であった（図-8）。

また，載荷試験による変形係数と割れ目集合体の変形係 数との対応関係を見ると, 割れ目集合体の変形係数は割れ

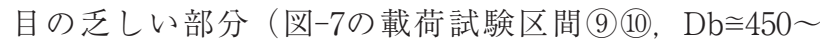
$500 \mathrm{MPa}$ ）のそれと比べて $1 / 10$ 程度となることが認められ た (図-8).

岩盤中において割れ目集合体は力学的に弱いゾーンとな り，岩盤が変形する過程では割れ目集合体に変形が集中す ると考えられる ${ }^{18)}$ 。今回の丸尾蛇紋岩では多くの割れ目集 合体に扔いて，変形係数（Dbz）は30〜40MPaであり，こ

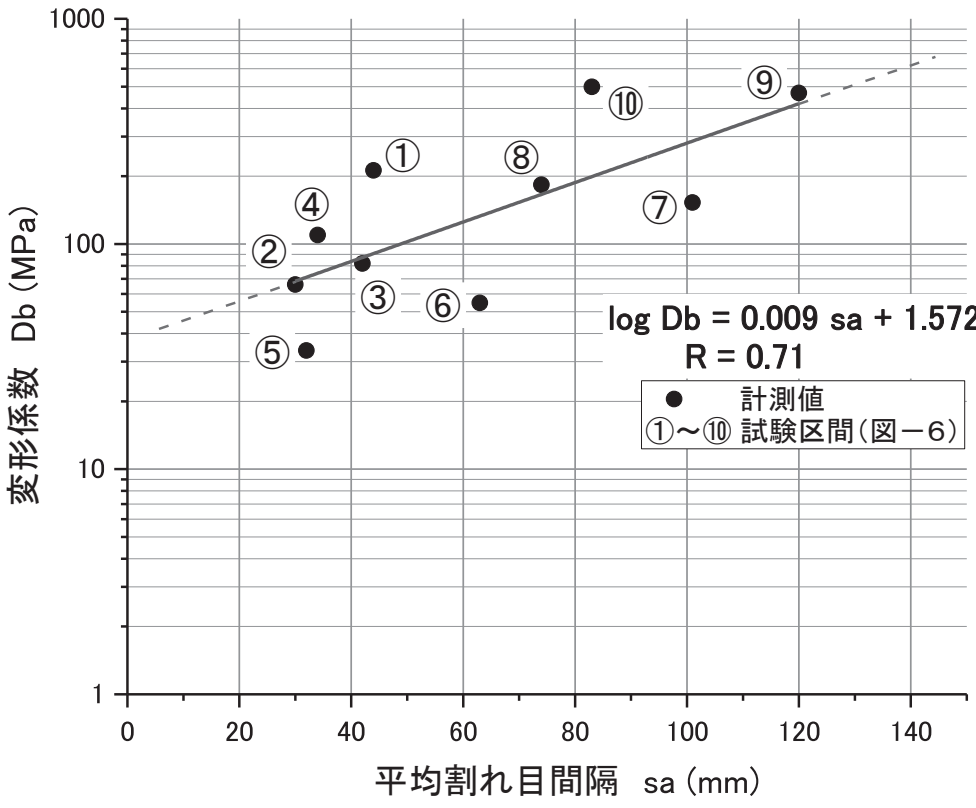

図-7 変形係数（計測值）と平均割れ目間隔の関係 $\mathrm{Db}:$ 変形係数 (計測值) $\mathrm{sa}$ : 平均割れ目間隔 $\mathrm{R}$ : 相関係数

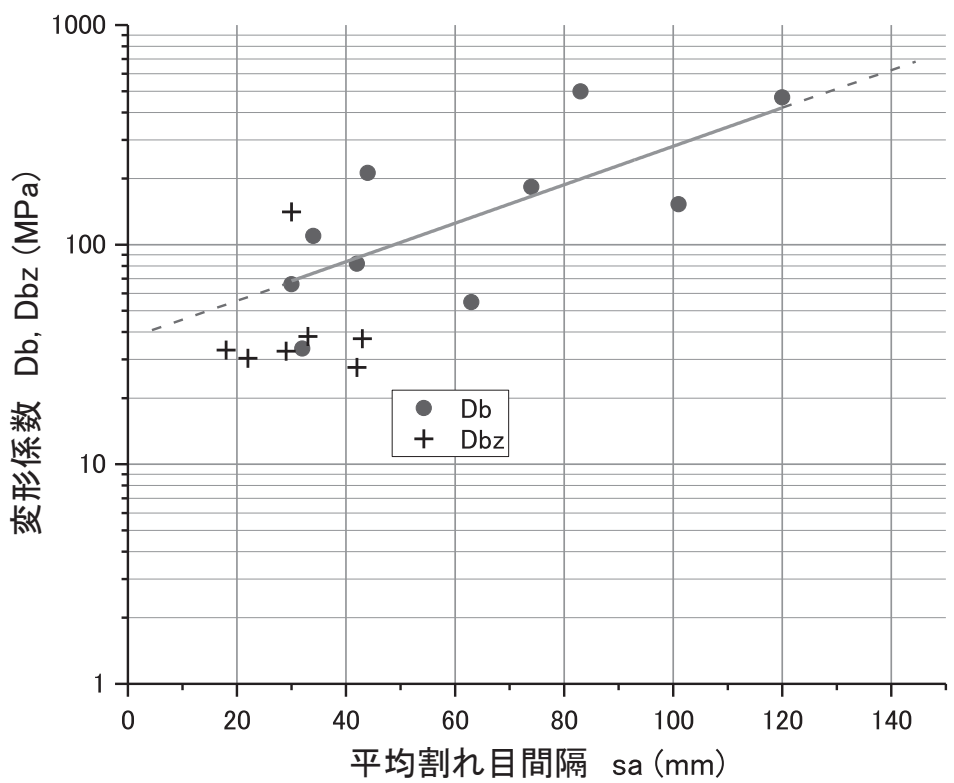

図-8 変形係数（計測値，推測値）と平均割れ目間隔の関係 $\mathrm{Db}$ : 変形係数 (計測値), 図 -7 と同じ.

$\mathrm{Dbz}$ : 割れ目集合体の変形係数（推測值） $\mathrm{sa}$ : 平均割れ目間隔

の值が未風化蛇紋岩の力学的に最も弱いゾーンの 1 つの目 安值となる。

割れ目集合体の存在は未風化岩盤では見過ごせない不連 続構造の要因となる。岩盤を不連続体としてモデル化する 際の不連続面の変形特性をどのように評価するかが問題と なっている ${ }^{6} . \mathrm{Dbz}$ はこのような問題への対応に寄与でき る可能性がある。今回の丸尾蛇紋岩の事例のように，割れ 目柱状図を作成して割れ目分布を記載し，割れ目集合体ご とに変形係数など各種の測定值を議論することは，他の蛇 
紋岩や異種岩相においても，岩盤の諸性質を割れ目分布の 実態に即して推測するうえで役立つと期待される。

\section{5. ま と}

（1）山口県宇部市丸尾地域での未風化の蛇紋岩のコア観察 （コアの割れ目スケッチ，図-2）に基づいて，割れ目柱状 図と割れ目間隔図を作成し，割れ目集合体を抽出した（図 -3)。割れ目集合体の平均的な厚さは $0.1 \sim 0.7 \mathrm{~m}$ 程度，割れ 目の数は $5 \sim 20$ 枚程度, 平均割れ目間隔は20〜 40mm程度で あった。

（2）孔内水平載荷試験の区間ごとに平均割れ目間隔（sa） を求めると, 平均割れ目間隔 ( $\mathrm{sa}$ ) と変形係数 $(\mathrm{Db})$ と の間に正の相関が認められ，変形係数は割れ目分布によっ ておおむね説明可能であることを示した（図-6，7）.

（3）一定間隔ごとに機械的に区切った孔内水平載荷試験の 結果では変形係数は30〜500MPaであったが（図-6, 7), 載荷試験結果を割れ目集合体ごとに割りふると, 変形係数 はほぼ30〜40MPaの範囲に集中する（図-8）。これが丸尾 蛇紋岩が割れ目集合体（平均割れ目間隔は20４0mm程度） に沿って変形する際の変形係数を与えていると考えられ る.

謝辞 本稿をまとめるにあたり，山口大学名誉教授加納 隆先生には原稿をお読みいただき，貴重なご意見を頂戴し た。心からお礼申しあげます。

\section{引 用 文 献}

1）梅津一晴（1995）：蛇紋岩の土木地質的一検討, 応用地質, Vol.36, No.5, pp.46-55.

2) Coleman, R.G. (1977): Ophiolites, Ancient Oceanic Lithosphere?, Minerals and Rocks 12, Springer-Verlag Berlin Heidelberg NewYork, pp.98-103.
3）平内健一・片山郁夫（2015）：蛇紋岩の力学的性質とそのテ クトニックな意義, 地学雑誌, Vol.124, No.3, pp.371-396.

4) 日比野 敏 (2007): 技術者に必要な岩盤の知識, 鹿島出版会, 166p.

5）ダム工学会編（2012）：総説 岩盤の地質調査と評価 現場技 術者必携 ダムのボーリング調査技術の体系と展開, 古今書 院, pp.307-328.

6）地盤工学会 設計用地盤定数の決め方一岩盤編一編集委員会 編（2014）: 設計用地盤定数の決め方一岩盤編一, 地盤工学会, pp.93-148.

7）地盤工学会 原位置岩盤試験データベース（2008年度版）編 集委員会編（2009）：原位置岩盤試験データベース（2008年 度版)，地盤工学会，pp.84-131.

8）全国地質調査業協会連合会編（2003）：ボーリングポケット ブック (第 4 版), オーム社, pp.442-447.

9）津田秀典（2014）：ボーリング割れ目柱状図と割れ目系孔間 断面図一グリムゼル岩盤試験場での事例一, 応用地質, Vol.55, No.5, pp.216-228.

10）端山好和・皆川 潤（1996）：割れ目, 新版地学事典（地学 団体研究会新版地学事典編集委員会編), 平凡社, pp.14411442 .

11）西村祐二郎·今岡照喜・金折裕司・亀谷 敦（2012）：山口 県地質図第 3 版（15万分の 1 ）, 山口地学会.

12）西村祐二郎（2009）：山口県宇部－小野田地域, 日本地方地 質誌 6 中国地方 (日本地質学会編), 朝倉書店, pp.204-205.

13）山口地学会編（1991）: 山口県の岩石図鑑, 第一学習社, p.131.

14）地盤工学会地盤調査規格・基準委員会編（2014）：地盤工学 会基準（JGS1531-2012）地盤の指標值を求めるためのプレッ シャーメー夕試験方法, 地盤調查の方法と解説一二分冊の 2 一, 丸善出版, pp.664-668

15）土木学会監修, 土木用語辞典編集委員会編 (1974): 変形係数, 土木用語辞典，コロナ社・技報堂，p.188.

16) Price, N.J. (1959) : Mechanics of Jointing in Rocks, Geol. Mag., Vol.96, pp.149-167.

17）三木幸蔵・古谷正和（1996）：土木技術者のための岩石・岩 盤図鑑, 鹿島出版会, pp.232-233.

18）ショルッ, H. (2010)：地震と断層の力学 第二版, 柳谷俊 · 中谷正生訳, 古今書院, pp.104-107.

（2015年 7 月31日受付，2017年 1 月20日受理） 
付表-1 割れ目データおよび孔内水平載荷試験データ

深度欄の薄墨部は孔内水平載荷試験の区間境界を示す。

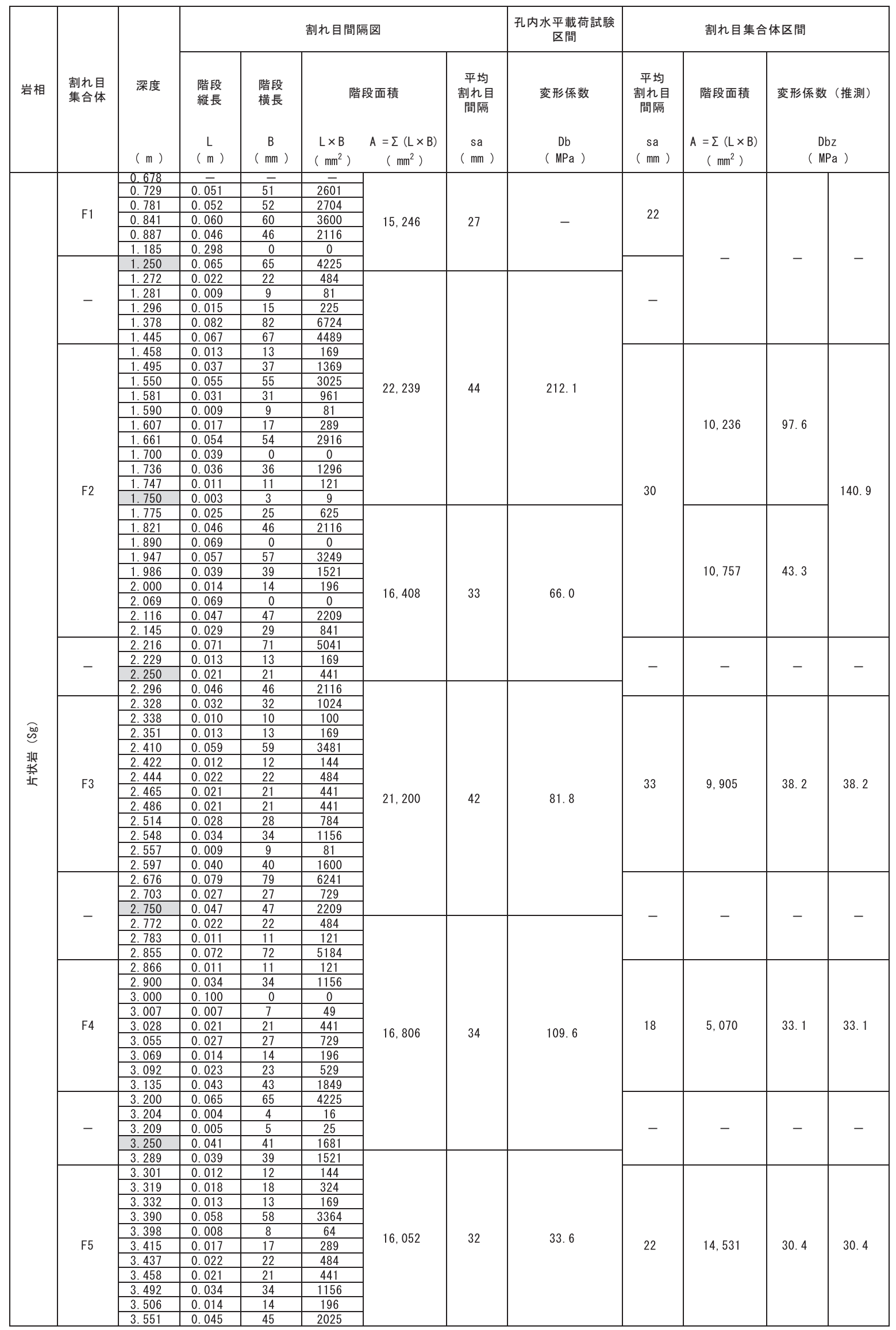


付表-1（続き） 割れ目データおよび孔内水平載荷試験データ

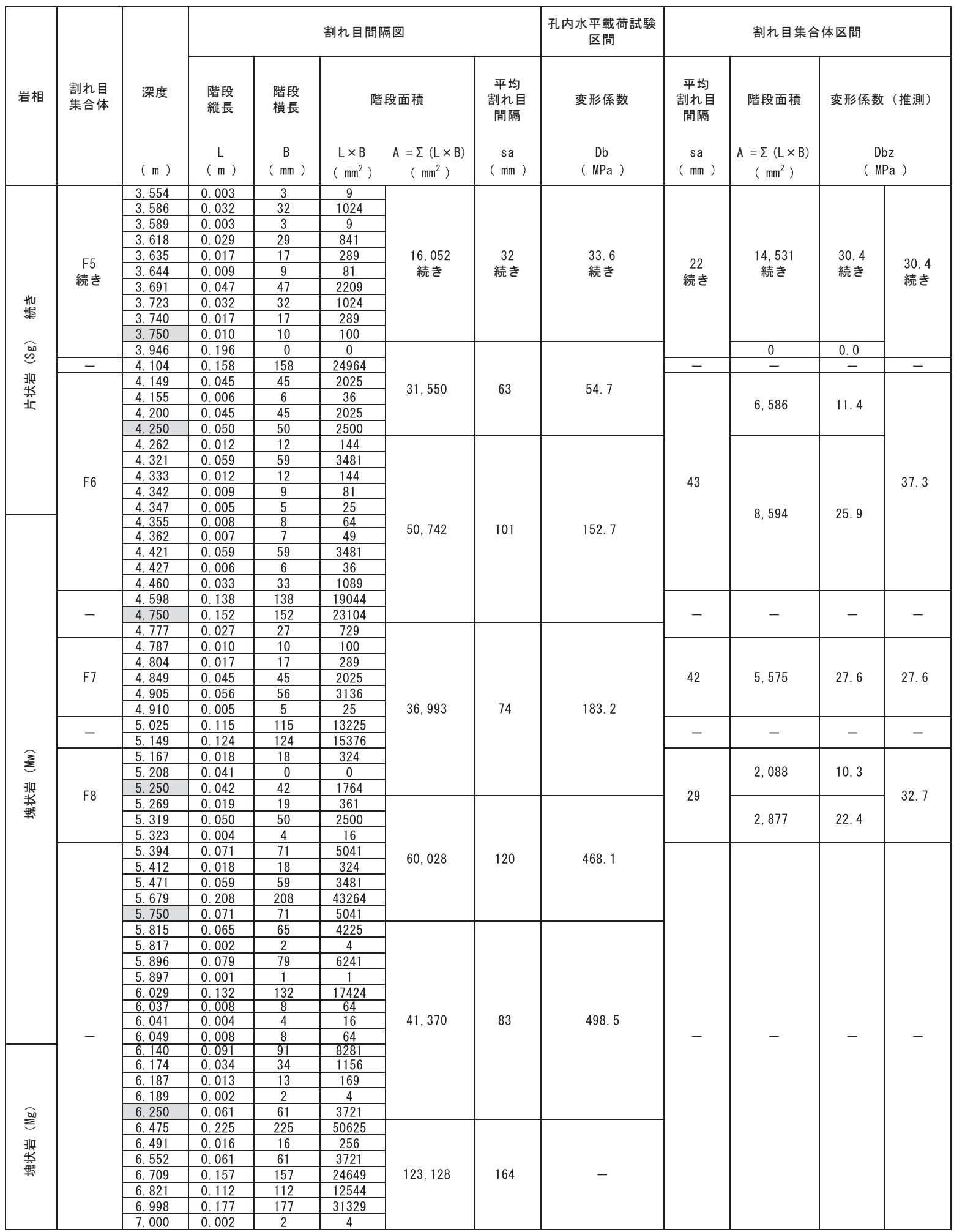


Jour. Japan Soc. Eng. Geol., Vol.58, No.1 pp.19-30, 2017

\title{
Fracture Distribution and Deformation Modulus on Serpentinite
} -A Case Study in the Maruo District, Ube City, Yamaguchi Prefecture, SW Japan-

\author{
Hidenori TSUDA
}

\begin{abstract}
Mode of occurrence and distribution of fractures are described on a boring core drilled in non-weathered serpentinite, exposed at the Ube coastal area, Yamaguchi Prefecture. The fracture tends to form a zone, named the fracture zone, composed of several fractures on the borehole fracture column. In the case of the Ube serpentinite body, a fracture zone includes 5 20 fractures and the mean fracture spacing is around $20 \sim 40 \mathrm{~mm}$. The deformation modulus obtained by pressure meter test in the borehole ranges $30 \sim 500 \mathrm{MPa}$, however, the re-calculated value of deformation modulus corresponding to the most fracture zone concentrates within 30 to $40 \mathrm{MPa}$. This value is ca. 1/10 of the nonfractured part, which gives the mean deformation modulus of fracture zones (weakened parts) of serpentinite.
\end{abstract}

Key words : fracture distribution, fracture zone, deformation modulus, serpentinite 